地すべり 第37巻 第3号

Journal of the Japan Landslide Society $37-3(2000)$

\title{
四国中央部御荷鉾帯の緑色岩の風化と地すべり $(1)$
}

Weathering processes and landslides occurrences of the Mikabu Greenstone Belt, central Shikoku, southwest Japan(1)

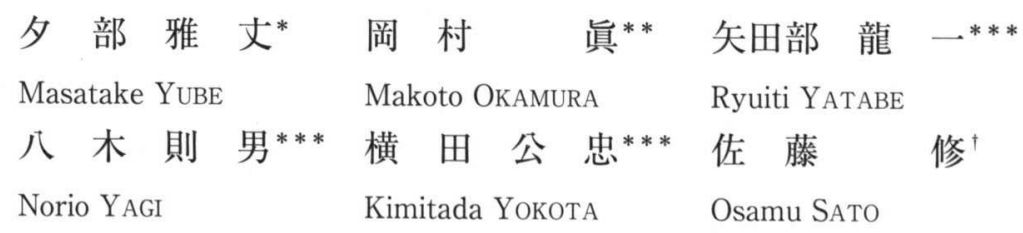

\begin{abstract}
The Mikabu Greenstone Belt is characterized by many creeping landslides with comparatively small slip angles. Landslide distribution in this belt corresponds to the distribution of schistose greenstone and obscures in massive greenstone. Schistose greenstone has well-developped cracks and cleavage, which cause an easy ground water permeation. Also, schistose greenstone being mainly composed of actinolite and chlorite can be easily hydrated. Weathering process of schistose greenstone begins with dissolution of $\mathrm{Ca}^{2+}$ at first, and formation of smectite then takes place after dissolution of $\mathrm{Mg}^{2+}$ from actinolite and chlorite. Thus, the physicochemical weathering processes seems to have progressively changed the petromineralogic properties of the rock.
\end{abstract}

キーワード : mineral, alteration, leaching, water quality

\section{1.はじめに}

四国山地の御荷鉾帯地域は, 地すべり地が密集して分 布しており，大地がたえまなく流動し，時に大災害をも たらす。一方，このような不安定性とはうらはらに，な だらかな斜面を持ち広い空を眺めることができるため, 牧歌的な風景がひろがり, 田畑が多い。この四国山地の 中心部であるにもかかわらず耕作地が多いというのは, 時に地すべり災害を被るものの, それ以上に地すべり活 動の結果, 作物の栽培に適するようにほぐされた大地で もあるという恩恵を受けているからで, 山地斜面として は特異な地帯を形成している。

本論ではこのように土木工学的には極めて特異な地質 帯である御荷鉾緑色岩類が分布する四国中央部の大豊町 蔭地区と土佐町松木野地区の地すべり（図-2 参照）を 中心に, この緑色岩の風化と地すべりの関係についてこ れまでの知見を述べる。

* 高知県 · 愛媛大学院

$* *$ 高知大学

*** 愛媛大学

$\dagger$ 新潟大学

\section{2. 御荷鉾帯の分布と形成年代}

御荷鉾類帯に地すべりが多発する原因のひとつとして, 構成岩類の成因が関係するため, 以下に成因論について 簡単に述べる。

西南日本外帯の構成要素のそれらのひとつである御荷 鉾帯は, 三波川帯の南縁部に関東山地から四国西部まで $800 \mathrm{~km}$ にわたって分布する地質帯（図－1）で，主とし て塩基性火山岩と超苦鉄質 - 苦鉄質岩より構成され, 南 側の秩父帯と接する。

御荷鉾帯は四国では最大幅 $5 \mathrm{~km}$ 程度で, 東西にレン ズ状に 4 つ程のブロックに分かれ，断続的に分布してい る。高知県では, 西石原から池川町の間は, 上八川一池 川構造線で三波川帯と秩父帯が直接接しており，この間 には御荷鉾帯は分布していない。5

御荷鉾帯の形成年代については，これまで塩基性岩に 伴われる堆積岩中の化石 (石炭紀, 三畳紀, ジュラ紀) から議論されてきたが, 化石の保存状態が悪く, その全 容は明らかになっていない。一方, 御荷鎍緑色岩は変成 作用を受け变質していることから, 火成起源の残留鉱物 として岩脈中に含まれる角閃石に注目し，K-Ar法を用 いて測定を行った結果, 鳥羽地域の火成岩の形成年代は 
150Ma前後（ジュラ紀）であるとしている (小澤6) 。さ らに小澤は，化学分析の結果から海台ではなく海山列で あることを示唆するとしているが，火成年代の全体像は 未だつかめていない。いずれにせよ，秩父帯の緑色岩に ついてもいえることではあるが，両帯の緑色岩が海底に 噴出した塩基性の火成起源のものであることが，地すべ りと大きな関係を有していることは間違いない。

\section{3．御荷鉾帯の地すべりの特徵}

高知県における地すべり防止区域に指定された地質帯 別の分布とそれぞれの地質帯別に地すべり防止区域が占 める面積の割合を図ー 2 に示す。先に述べたように，御 荷鉾帯は圧倒的に地すべりの割合が高い地質帯であるこ とを示している。

また，御荷鉾帯の北側に分布する三波川帯の地すべり と南側に分布する秩父帯の地すべりの斜面勾配はおおむ

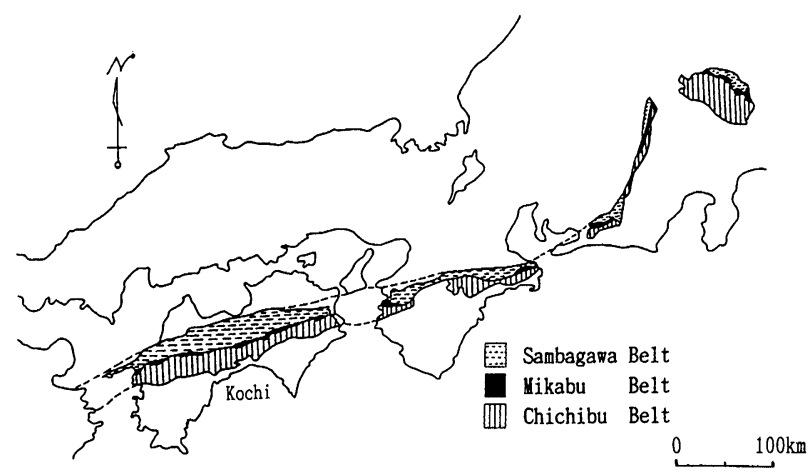

図-1 御荷鉾緑色岩類帯の分布図
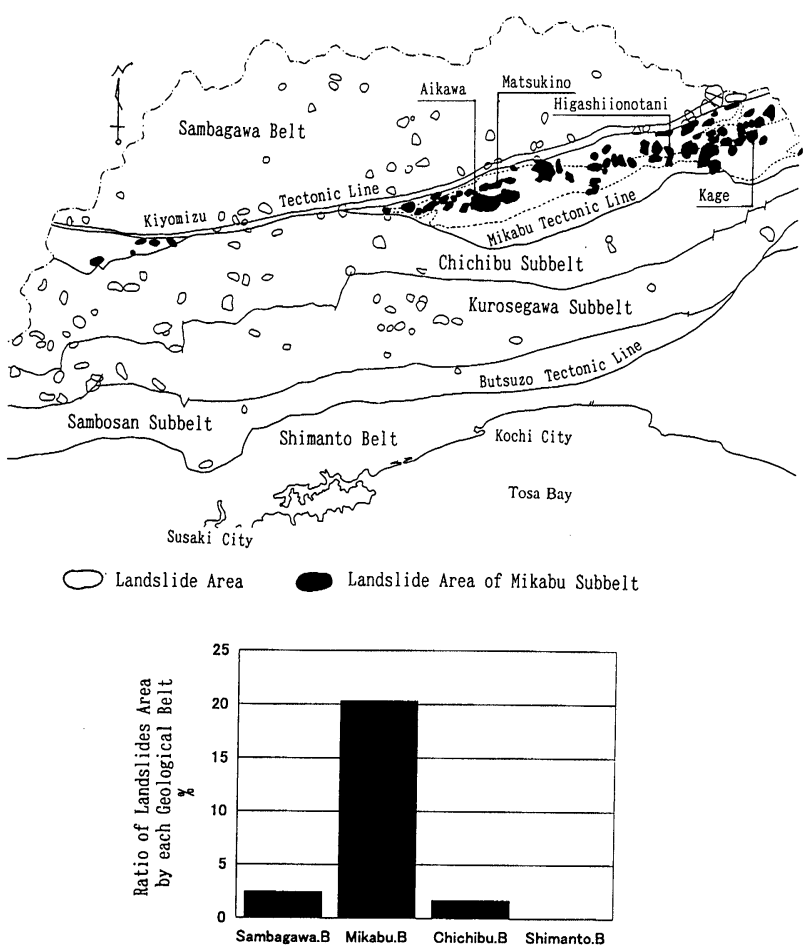

图ー2 高知県の地すべり分布と地質帯別地すべりの割合
ね20度以上で, 地下水位が低く, 田がほとんどなく畑地 耕作が主体である。これに対し御荷鉾帯の地すべりは, 一般に斜面勾配がなだらかでおおむね20度以下であり， 地下水位が高く田が多く耕作されている。御荷鉾帯に位 置する蔭地すべり防止区域内の田畑は，51haにおよび， 耕作地が地すべり防止区域の70\%を占め, 高い土地利用 がなされている。

また，三波川帯並びに秩父帯の地すべりが，豪雨など により急激に滑動するのに対し，御荷鉾帯の地すべりは， 年間を通じて動いており，日本海側の第三紀層地すべり に似たクリープ的な滑動をしている。これは，八木ら ${ }^{19)}$ の御荷鉾帯のすべり面粘土のクリープ試験によるひずみ 速度の結果も, 三波川帯や秩父帯のものよりも第三紀層 のすべり面粘土に近い值を示しており, 力学試験結果か らも御荷鉾帯と第三紀層のすべり面粘土の力学特性の類 似性を指摘することができる。

\section{4. 御荷鉾緑色岩類と構成鉱物}

\section{1 構成岩類}

対象地域の構成岩類は，火成岩としては，ハイアロク ラスタイト，枕状玄武岩，ピローブレチャ，はんれい岩， 蛇紋岩, 斜長石花崗岩で, 堆積岩としては, チャート, 頁岩, 石灰岩である。

\section{2 構成鉱物}

これまで筆者が同定した御荷鉾緑色岩を構成する鉱物 としては, クロライト, アクチノライト, アルバイト, エピドート，パンペリーアイト，オージャイト，ス フェーン, カルサイト, カルコパイライト, クウォーツ, サーペンチナイト，スチルプノメレーンである。

\section{3 地すべり帯の緑色岩と構成鉱物}

地すべり帯の緑色岩は片状を呈しており，構成鉱物は 主としてアクチノライトおよびクロライトで構成されて いるのが特徴である。なお，地すべり帯にも転石状やレ ンズ状に塊状緑色岩が存在する場合もあるが，これは回 りを片状岩で取り囲まれていた塊状緑色岩が，地すべり に取り込まれ移動土塊として滑動しているものと考えら れる。

先に述べたように，御荷鉾帯の中でも，地すべりは片 状の緑色岩帯（ほぼハイアロクラスタイト帯）で発生し ており，塊状の緑色岩類帯には地すべりはほとんど発生 していない。これの例示として，図－3に蔭地すべりが 位置する南小川地区と松木野地すべりが位置する伊勢川 地区の地すべりの分布を左側に示し，右側には岩相およ び鉱物共生として，アクチノライトとクロライトから構 成される片状の緑色岩を×で，またこれらの鉱物の他に アルバイトなどが加わる塊状の緑色岩を○で表した図を 並べて示す。右図の実線は, 斜面勾配の急緩の変換点で, かつ塊状と片状の緑色岩の境界を示す。左図の地すべり 指定地は，行政管理上の区域であるため，土地利用の重 要度や変状の大きさなどを勘案し指定されており, 右図 
と必ずしも対応していない部分もあるが，×印の区域は 緩斜面であり，また，地すべりは，ほぼ印区域で発生 しており，一方の印の区域は急斜面の山体を形成してい ることが分かる。

\section{5. 岩石構造および構成鉱物の化学特性と風化}

\section{1 岩石構造}

御荷鉡緑色岩には片理構造が著しく発達しているもの がある。片理はしばしば片状鉱物によって特徴づけられ， 御荷鉝緑色岩の場合, $1 \mathrm{~mm}$ 前後の胡麻を潰したような 黒色のクロライトが観察される。また, 䢃開や節理が発 達しており，楔状に割れたり鱗状にはがれるものもある。
地すべり帯の御荷鉾緑色岩は，図ー4に示すように片 理と辟開が斜交しており地下水が岩石中に浸透しやすい 構造となっている。このため, このような片状緑色岩は 風化に対して極めて敏感であると言える。これに対し, 三波川帯の緑色片岩は高圧の変成作用を受けて硬質化 · 塊状化しているものは, 縞模様が発達し厚い板状を呈す るため, 石のテーブルとして利用されるなど，片状構造 を持つ御荷鉾緑色岩が細片化するのとは違った構造をし ている。また，秩父帯の緑色岩は分布の厚さがあまり無 いことと，クウォーツをはじめアルバイト，雲母など多 種の鉱物から構成されており, 風化した片状の御荷錚緑 色岩が細片状にバラバラになりやすいのに対し，若干板
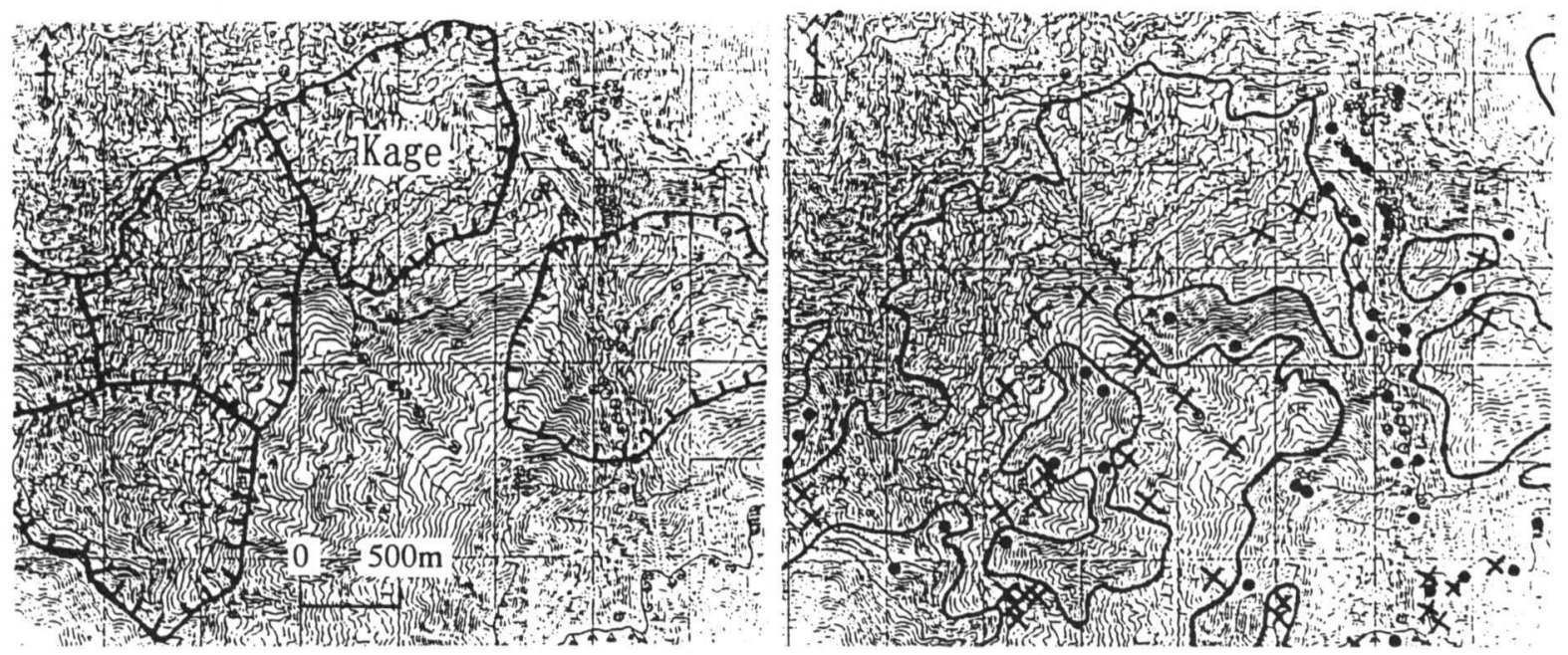

凡例 南小川流域の地すべり分布と岩相・鉱物共生および斜面勾配関係図
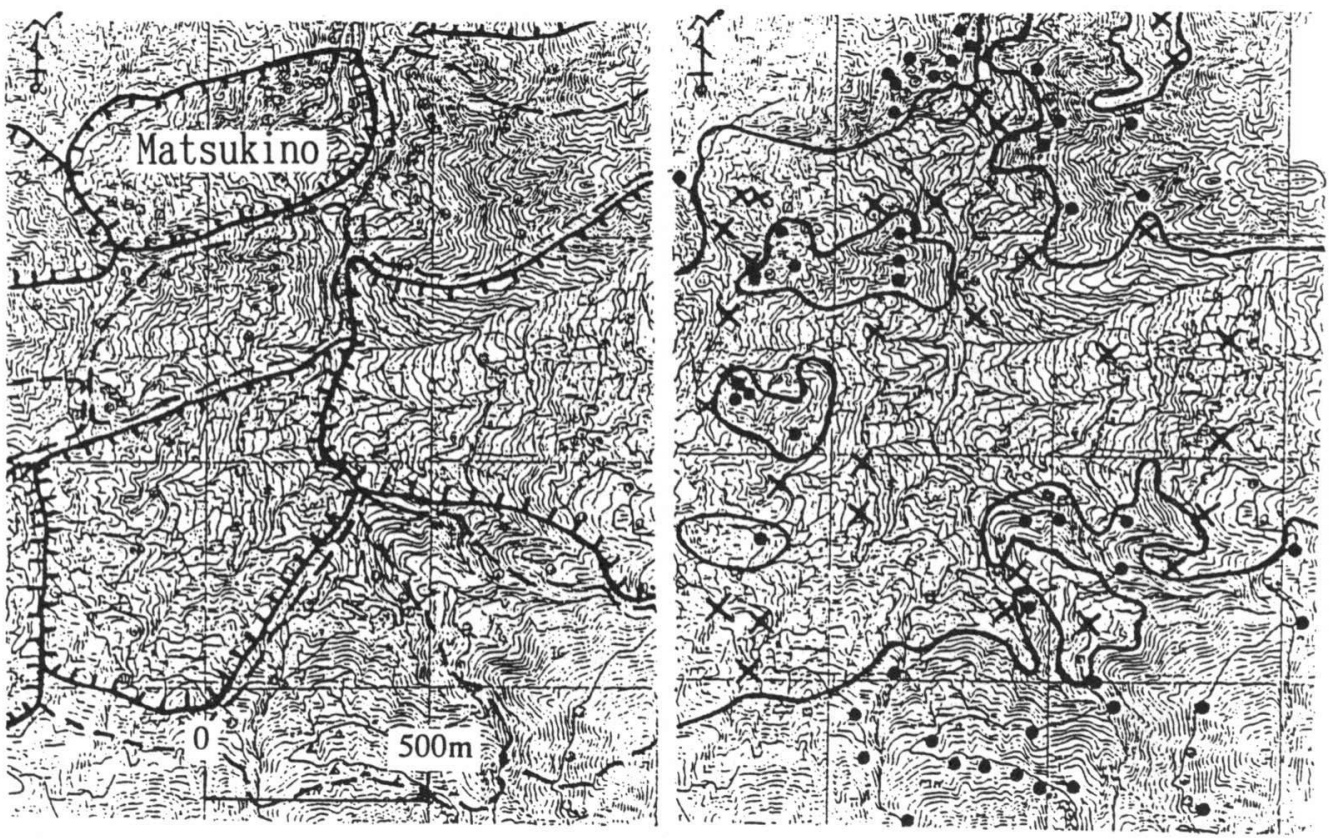

凡例

:危険区域 $\mathrm{X}: \mathrm{Ac}+\mathrm{Ch}$

$: A c+C h+A I\left(3 N N^{\circ}\right.$ 1 $)$

伊孜川流域の地すべり分布と岩相・鉱物共生および斜面勾配関倸図

図ー3 御荷鉾帯の地すべり分布と岩相図 
状を呈するなどの産状を持つ違いがある。

薄片の鏡下化観察では, 写真 -1 に示すように，片状 の御荷鏾緑色岩は, 写真中央部の細粒の結晶質部と両側 のガラス質部が交互に重なっている。

このような構造は, 温度変化による膨張収縮の異方性 や水の浸透のし易さの差など, 微細レベルにおいても, 物理的・化学的風化の程度に差異があり, 風化し易い構 造となっているといえる。これは，御荷鉾緑色岩が約 1 億 5 千年前に海底に噴出した時, 噴出時に溶岩と海水と の接触により，後に述べるような化学的反応をおこして いること，その後のプレート運動による沈み込みにより 低温高圧の三波川変成作用を受けたこと, 続いて現在の 位置まで隆起してきたことなど，さまざまなテクトニッ クな過程をたどって来ており，この間に鉱物の変質や形 態の変化などの経緯の結果生じた岩石構造である。

\section{2 構成鉱物の風化特性}

フィールドでは，片状の緑色岩の風化が著しいものの, 塊状の緑色岩は岩体として風化せずに露出しているのを 観察することが出来る。風化あるいは細片崩壊している 片状緑色岩の構成鉱物はアクチノライトとクロライトが 主体であり, 新鮮な場合には緑色を示すが, 風化すると 灰色を呈していることが多い。

また，断層や亀裂に黒色の $1 \mathrm{~cm}$ 数 $\mathrm{mm}$ の厚さのク ロライトが，また，断層の直近や岩すべり面では緑色ま たは白色で濃集したアクチノライトを観察することがで きる。アクチノライトは新鮮なものは針状で暗緑色を呈 しているが, 露頭では風化して白く見える。

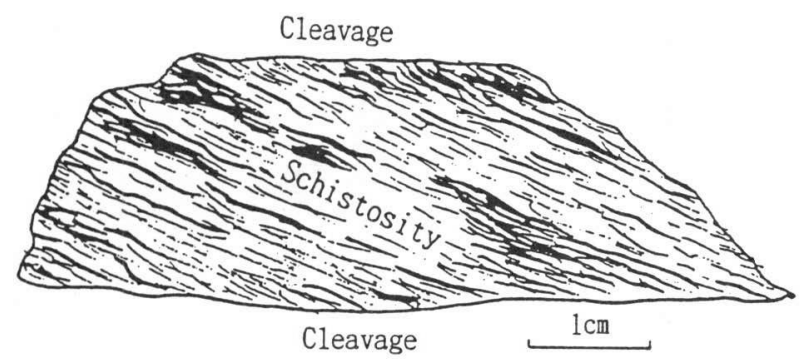

図－4 片状緑色岩断面図

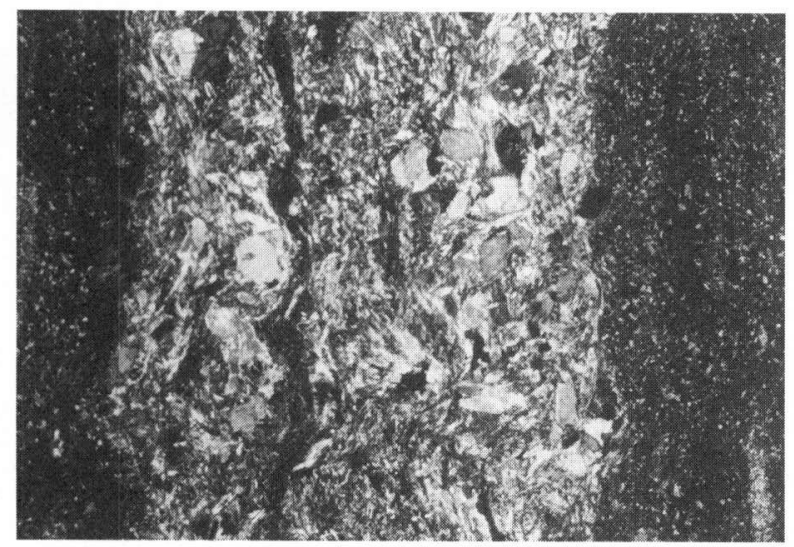

写真-1 岩石薄片写真（横幅6. $6 \mathrm{~mm} \times$ 縦長4.6mm）
これらのことや後に述べる化学分析や水質分析から片 状の緑色岩の風化は, 元素で言えばアクチノライトの Caがまず溶脱し，風化が進行していくものと考えられ， Caはアクチノライトに含まれるが, クロライトには微 量にしか含まれないことから, アクチノライトは片状の 御荷鉾緑色岩の風化の鍵をにぎる鉱物であるといえる。 つぎにアクチノライトおよびクロライトの Mgが溶脱し ていく。 Mgの溶脱状況については蛍光X線および水質 の項で述べる。

4.3で述べたように, 地すべりは片状の緑色岩帯で発 生している。これに対し, 山体部は塊状の緑色岩から 成っている。これらの岩石を構成する鉱物を調べるため に, 蔭地区の山体部と地すべり帯部の岩石のXRDを実 施した（図 -5 )。

その結果，地すべり帯部の岩石は，先に述べたように， 主としてアクチノライトとクロライトから構成されるの に対し，山体部の岩石はこれらの鉱物に加えアルバイト， オージャイト（パンペリーアイトやエピドートが含まれ る場合もある）などから構成されていることがわかった。 松木野地すべりでも同じことがいえ, 図-6に松木野の 山体および地すべり帯部の鉱物出現図を示す。

次に岩石とすべり面粘土, および片状の緑色岩の構成 鉱物の蛍光X線分析結果について述べる。蛍光X線分析 は, 風化変質を調べるために, 片状の風化緑色岩とすべ り面粘土について, また片状の緑色岩の主構成鉱物は, アクチノライトとクロライトであるが, 風化変質におけ る元素移動にどの鉱物のどの元素が関係しているのかを 調べるために, クロライトとアクチノライトの元素分析 を行った。

岩石とすべり面粘土は, 愛媛大学のPHILIPS社製PW 2400 を使い, 粉砕した試料を無水四ホウ酸リチウムと混 合して溶融させたガラスビードを使用した。融剤は
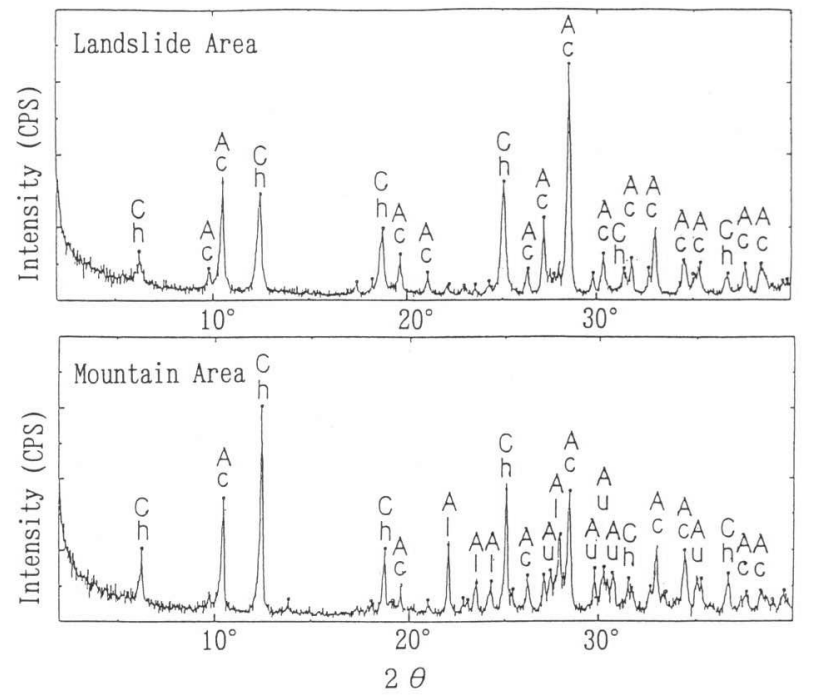

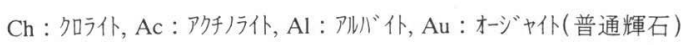

図ー5 荃地すべりの山体部と地すべり帯部岩石のXRD 
MERCK社製の無水四ホウ酸リチウム（ロット10,783） を用いた。ビード作成の岩石粉末はあらかじめ $1 \mathrm{~g}$ 程度

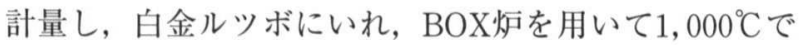
3 時間灼熱した。この無水試料を正確に $0.5 \mathrm{~g}$ を秤量し, 岩石粉末と融剂の比率が正確に $1 ： 10$ になるように調合 した。これをめのう乳鉢中で両者を十分混合させ，白金 と金の合金からなるルッボに移し，ビードサンプラー (PHILIPS社Perl'X3型全自動ビードサンプラー) で溶融 しビードを作成した。ビードの直径は $4 \mathrm{~cm}$ である。管 球はRh対陰極管を使用している。

また，鉱物試料に対しては同大学の地域共同研究セン ターの堀場製作所のXGT-2000/2000Vを使い，めのう 乳鉢で粉砕した粉末を用いた。

風化岩と粘土の蛍光X線分析結果を図 - 7 に, 構成鉱 物の同分析結果を図-8に示す。

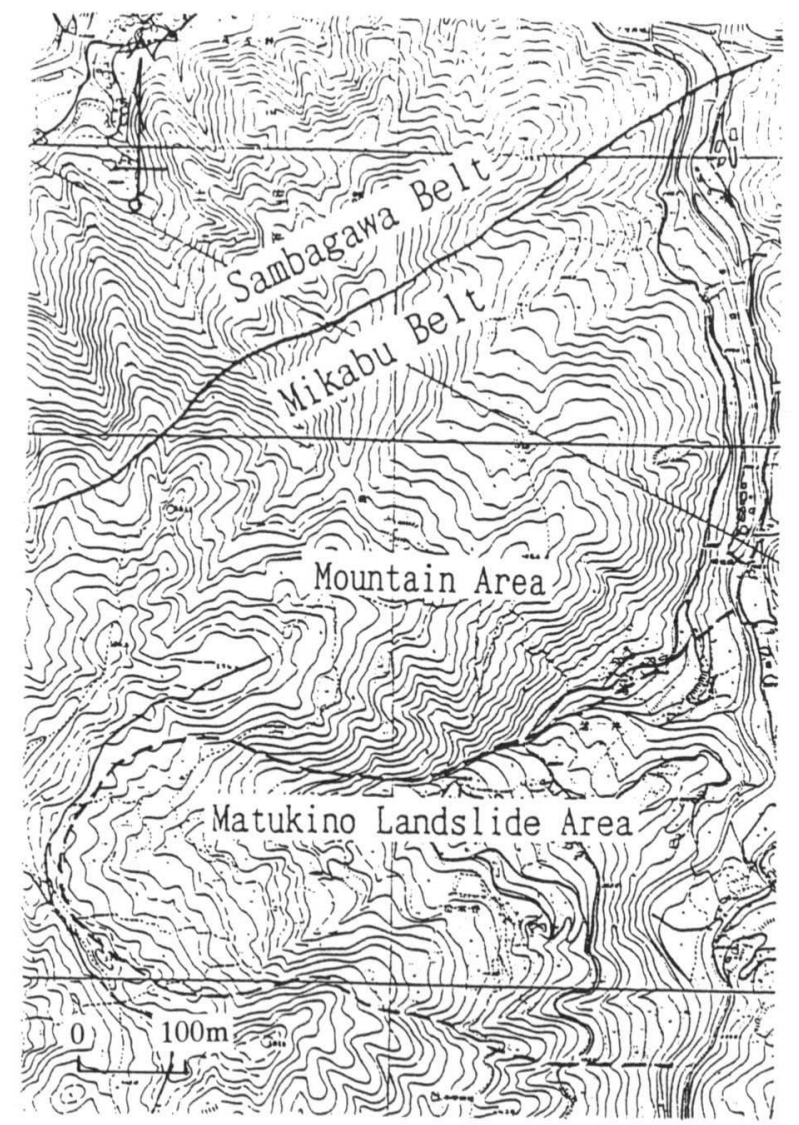

\begin{tabular}{|c|c|c|}
\hline & Mountain Area & Landslide Area \\
\hline \multirow{2}{*}{\multicolumn{3}{|c|}{ Chlorite }} \\
\hline & & \\
\hline \multicolumn{3}{|l|}{ Augi te } \\
\hline Sphene & . & ...................... \\
\hline \multicolumn{3}{|l|}{ Albi te } \\
\hline Epidote & - & \\
\hline Pumpellyite & - & \\
\hline
\end{tabular}

\begin{tabular}{|c|c|}
\hline & $\begin{array}{l}\text { abundant to common } \\
\text { few to rare }\end{array}$ \\
\hline & blank means disappearanc \\
\hline
\end{tabular}

図ー6 松木野地すべりの山体部と地すべり帯部の出現鉱物
風化岩とすべり面粘土を比較すると, $\mathrm{MgO}$ 含有量は 粘土の方が低くなっている。

ところで, 御荷銷緑色岩はMgが多い。これはもとも とこの緑色岩が $\mathrm{Mg}$ の多いマグマに由来するとする説と, マグマが海水にふれて, 海水と岩石が反応を起こし, 海 水から岩石へ $\mathrm{Mg}$ が移行したためとされる説がある。 た, $\mathrm{CaO}$ が減少するのは海水中の $\mathrm{Mg}^{2+}$ と岩石中のCa長 石が以下の反応を起こすためで，また， $\mathrm{SiO}_{2}$ が滅少する のは $\mathrm{SiO}_{2}$ 含有量が少ない $\mathrm{Mg}$-クロライトが生成するため であると言われている。

$\mathrm{Mg}^{2+}+\mathrm{Ca}$ 長石 $\rightarrow \mathrm{Mg}$-クロライト + $\mathrm{Ca}^{2+}+\mathrm{SiO}_{2}{ }^{2+}$

海水中の 岩石中の

$$
\begin{gathered}
\mathrm{Mg}^{2+}+\mathrm{CaO} \rightarrow \\
\text { スメクタイトまたはクロライト } \\
\mathrm{MgO}
\end{gathered} \quad \begin{aligned}
& \text { 変質海水中へ } \\
& +\mathrm{Ca}^{2+}{ }^{2)}
\end{aligned}
$$

しかしながら，秩父帯の緑色岩も噴出条件にあまり違 いはないと考えられるものの, 御荷鉾帯の緑色岩の $\mathrm{MgO}$ が $20 \mathrm{wt} \%$ 前後に対し，秩父带の緑色岩では $8 \mathrm{wt} \%$ 前後であり, Mg成分は御荷鉾带の緑色岩ほど高くなく,
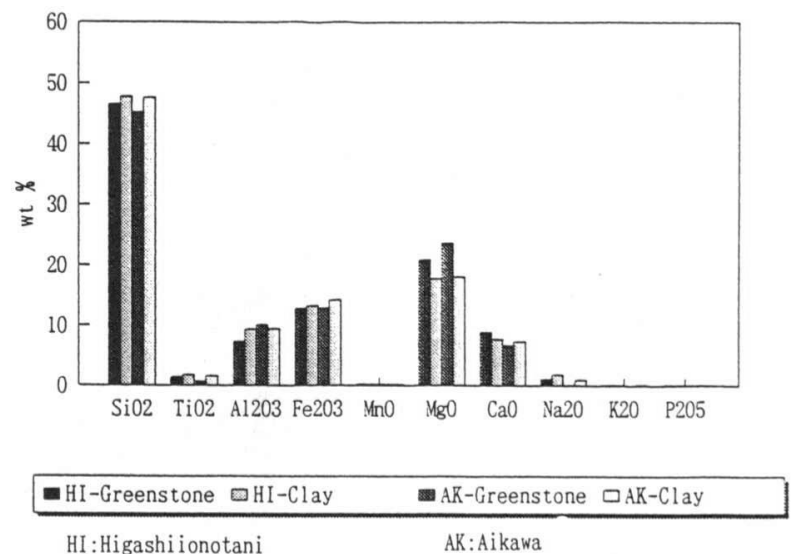

図-7 蛍光X線分析結果（風化岩，粘土）

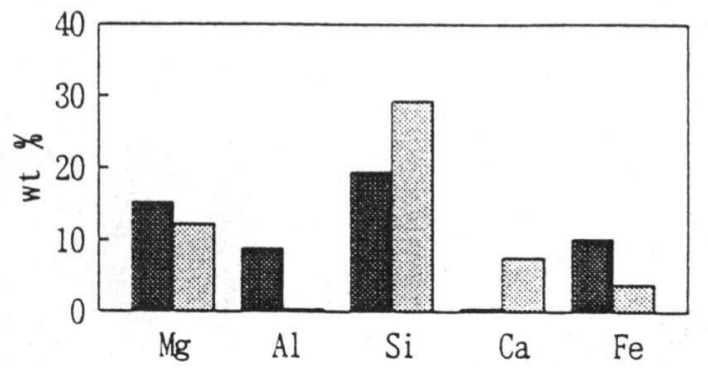

andorite

図－8 蛍光X線分析結果（構成鉱物） 
逆に御荷鉾帯の緑色岩のCaが $7 \sim 9 \mathrm{wt} \%$ に対し, 秩父 帯の緑色岩は10～13wt\%とCa成分は高くカルサイトが 認められる。したがって，Mgを一定海水から取り込ん でいるにしても，御荷錊帯の緑色岩のマグマは，もとも とMgが高いものであったと考えられる。

次に, 片状緑色岩を構成している, 変質鉱物であるア クチノライトとクロライトの源鉱物がなんであったかを 考察する。鉱物の分析結果（図－8）によれば，アクチ ノライトはSiが多く, $\mathrm{Al}, \mathrm{Fe}$ が少ない。ことにAlが極 端に少ない。このことからアクチノライトは単斜輝石か ら変質したものではないかと考えられる。アクチノライ 卜の組成は, 輝石類の中でCaをかなり含む透輝石や普 通輝石に水が加わったようなもの ${ }^{11}$ であり，また，鏡下 観察では輝石の残晶の周りにアクチノライトが見られる ことや，単斜輝石はCaを含み，Alが少ない。これらの ことはアクチノライトの源鉱物がCaをかなり含む輝石 類であることを支持するものであろう。なお Takeda' ${ }^{1}$ は， アクチノライトは単斜輝石と褐色普通角閃石から変質し たものとしている。

クロライトは, $\mathrm{Mg}, \mathrm{Al}, \mathrm{Fe}$ の構成比が高く, $\mathrm{Si}, \mathrm{Ca}$ が低い。ことにAlが高く, Caが極端に低い。これは上

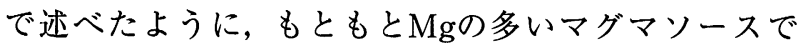
あったうえ $\mathrm{Mg}$ を海水から取り込み，Caを海水中で放出 するからであろう。クロライトは, 雲母, 角閃石, 輝石,

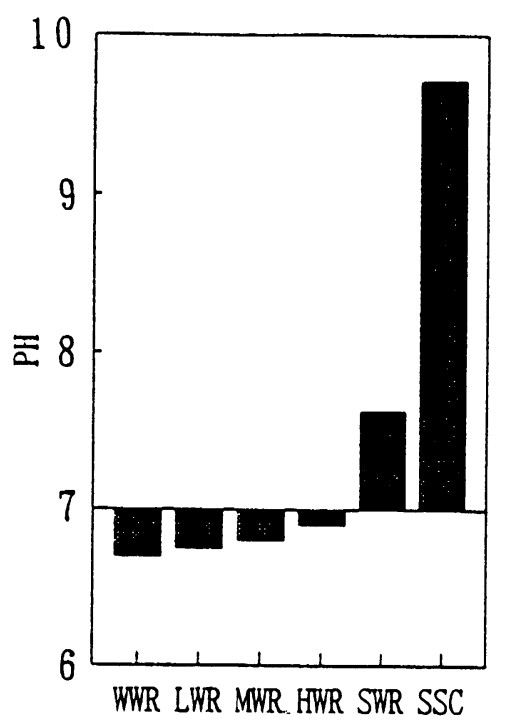

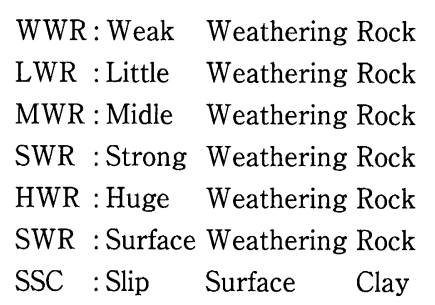

from left side

图一 9 アブレージョンPH
オリビンなどから変質する ${ }^{15)}$ と言われているが，長石は Alを多量に含むことから, クロライトの源鉱物として 長石類も考えられる。なお， Takeda" ${ }^{11}$ は，クロライトは ガラスオリビン, 単斜輝石, 褐色普通角閃石から変質し たものとしている。

図ー 9 に弱風化岩から粘土までのアブレージョンPH を示す。弱風化岩 6.7 , 中風化岩 6.75 , 強風化岩 6.80 , 超風化岩6.90, 表層風化粘土7.63, すべり面粘土9.71で 風化が進むにしたがい弱酸性から弱アルカリに移行して おり，地すべり粘土が一番高い值を示している。

\section{6 . 水質分析}

地すべりを滑動させるものとして最も重要な関わりを 持つのは地下水である。地下水中の溶存物質の大部分は, 地層中を流動するあいだに岩石や有機物などの反応でも たらされる。つまり, 地下水は地層を流動するあいだに 岩石などを溶解して水質成分を獲得するのである。この 研究では水の化学成分を調べ, 水が接していた鉱物と対 比させ，進行中の風化過程を推定する。

図ー10に東庵谷（下）地すべりの水質分析結果を示す。 すべり面は崩積土層と風化層の境界（8.1m深度）にあ る。すべり面付近では, 温度, $\mathrm{PH}$, 電気伝導度共に低 くなっており，地下水の流動層となっている。表層水は 一般の表層水と比べ御荷鋅緑色岩带を反映してMgが非 常に高い。また，すべり面周辺の水でも $\mathrm{Mg}$ の值が高く なって扔り，このすべり面粘土からはスメクタイトが同 定されている。

風化層と基岩の境界（27.5m，ほほ基岩中）の水質は 無穴孔から採取しており, 最深部の水質を反映している と考えられる。この水のCa值は高く, 表層およびすべ り面では $\mathrm{Mg}$ の溶脱が高いのに対して, 孔底に分布する 御荷鈝緑色岩は, $\mathrm{Ca}$ の溶脱が高く, 風化変質の進行に よる溶脱元素の違いを示しているものと考えられる。

$\mathrm{Mg}$ はももと移動度が大きい元素であり, $\mathrm{Mg}$ の移 動度は原岩がMgに富む岩石であるほど大きくなる傾向 がある。また，PHの低下とともに増大するとされてい る。

一般的には, 岩石成分の化学的風化の損失順位は, $\mathrm{Ca}, \mathrm{Mg}, \mathrm{Na}>\mathrm{K}>\mathrm{Si}>\mathrm{Al}, \mathrm{Fe}$ と言われているが ${ }^{18)}, こ$ こでも同じく $\mathrm{Ca}, \mathrm{Mg}$ の溶出が高くなっている。

なお，別途行った塩酸，硫酸，硝酸による御荷鋅緑色 岩の溶出実験では, $\mathrm{Mg}^{2+}, \mathrm{Fe}$ が多く溶け出している。 また, 蛍光X線分析による岩石面の元素マッピングでも, CaおよびFeが試料面全体にプロットされており，Caの みならずFeが風化に果たす役割には大きなものがある と考えられるが, これの解明は今後の課題である。

\section{7. 御荷鉾緑色岩の風化と地すべり粘土}

御荷錚帯の地すべりでは, すべり面粘土の多数にスメ クタイトが同定されるが，地すべりはほとんどの場合ク 


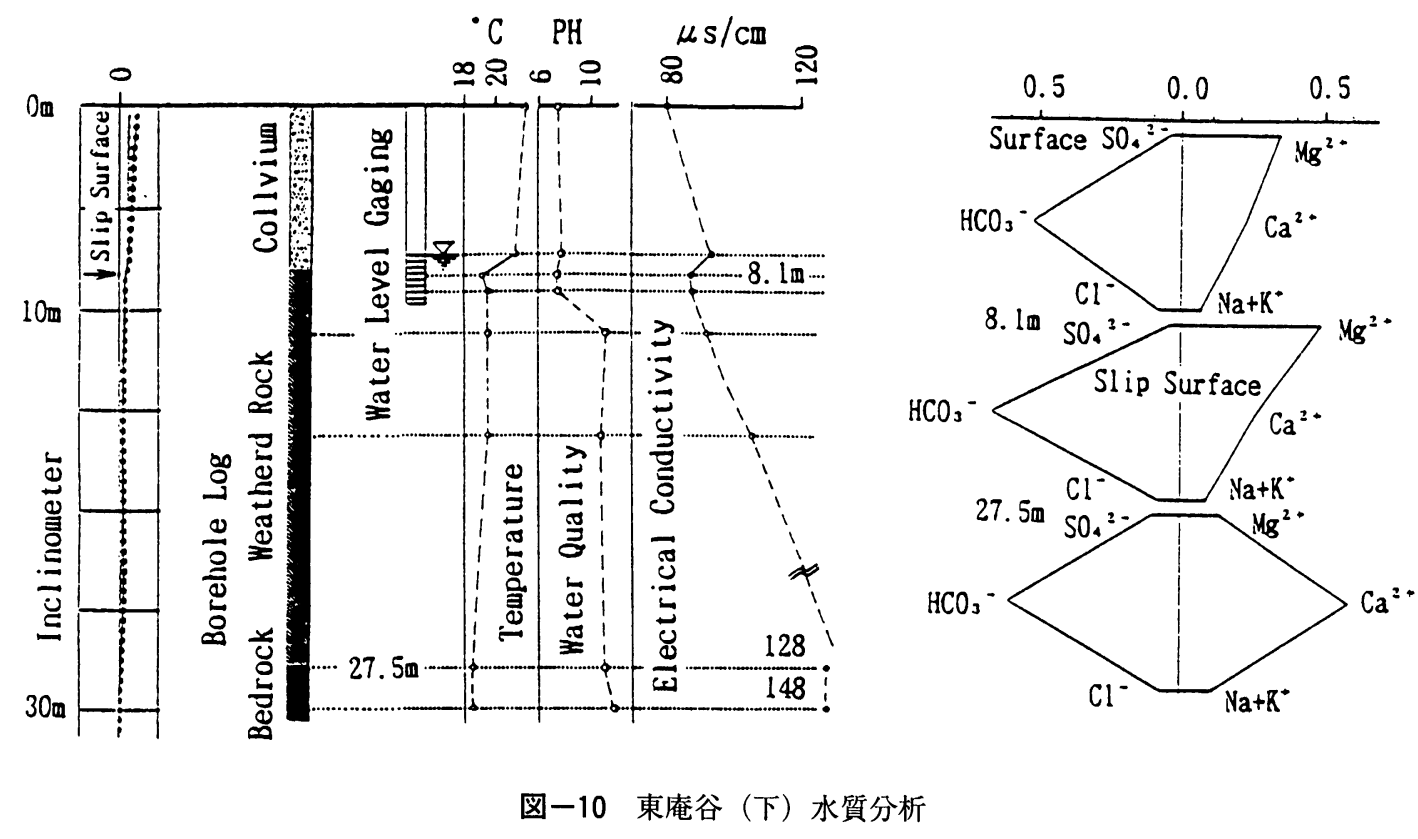

ロライトおよびアクチノライトから構成される片状の緑 色岩帯（ほほハイアロクラスタイト帯）で発生しており, スメクタイトはこのふたつの鉱物から生成されたものと 考えられる。

クロライトからスメクタイトが生成されることは, Stephen, I and MacEwan, D. M. C. ${ }^{12)}$ PStefano C et $\mathrm{al}^{13)}$, 守随 ${ }^{20)}$, 千木良 ${ }^{21)}$ な゙が指摘している。秩父帯地すべり の谷ノ内や打木, 大久保, 楠神などでもクロライトを主 体とする緑色岩起源のすべり面粘土からスメクタイトを 同定している ${ }^{23)}$ 。また, 角閃石からスメクタイトが生成 されることは, Stephen, I and MacEwan, D. M. C. ${ }^{12)}$ 指摘している。

ことにアクチノライトの場合には繊維状結晶であるこ ととCaを含むことが化学的風化に敏感に反応する要因 である。Caはイオン半径が大きく，ゆえにCaを含む鉱 物は結晶構造に無理があり, 結合が弱くなっている ${ }^{25} こ$ とで風化しやすいといえる。

また, アクチノライト，クロライト共に含水鉱物であ $\eta^{17)}$ ，水との親和性が非常に良い。水酸基を持たない例 えばクウォーツや長石の粉末が，XRD試料作成時にガ ラス上に滴下した水滴の上に浮かぶのに対し，アクチノ ライトとクロライトは, 水滴の中に浸透していくように, 瞬時に純水と一体となってしまう。このことは, 地下水 がアクチノライトやクロライトを持つ岩中に容易に浸透 するであろうことと, つづいて化学的風化が促進するこ とを想像するのは難しくない。

御荷鉾緑色岩は海底噴出生成後に続くサブダクション による圧力と変成作用, そしてその後の隆起による応力 開放等を受けて陸化している。これらの結果として緑色 岩は, (1)岩石構造として片理・䢃開と亀裂が発達し, (2) そして, 構成鉱物がクロライトは鱗状, アクチノライト は繊維状であること, (3)および構成元素として移動度の
高いCa， Mgに富むなどの特徴があり，御荷鉾緑色岩の 深層風化の原因となっている。

そして，すべり面粘土からスメクタイトが同定されて いることから，クロライトとアクチノライトの両鉣物か

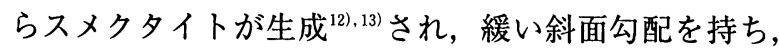
クリープ的に滑動する性格を持つ地すべりとなるものと 考えられる。なお，御荷鉾緑色岩の風化は，岩石生成環 境と変成度の違いなどによる岩相（片状と塊状）と鉱物 組み合わせ（アルバイトが混じると風化しにくい）も大 きな要因となっているが, 鉱物の風化過程（アクチノラ イト，クロライトの風化と $\mathrm{Ca}, \mathrm{Fe}, \mathrm{Mg}$ の移動）と共に 次回に述べたい。

\section{8. おわりに}

片状の御荷鉾緑色岩の風化は, アクチノライトことに 同鉱物中のCaそしてアクチノライトとクロライト中の $\mathrm{Mg}$ の溶脱風化によって進行し地すべり粘土が生成され ることを, 岩石・鉱物学的にフィールドでの観察と化学 分析，水質分析により明らかにしてきた。今後の課題と しては, 岩石および鉱物の粉末や岩片による各種の溶出 実験を行い，より風化機構を明確にしていくことである。

最後に本論は高知大学の鈴木克士名誉教授の先駆的な 研究 ${ }^{18)}$ があり, 先生には種々御教示いただいた。また， 愛媛大学の榊原正幸博士には岩石と粘土の蛍光X線分析 でお世話になった。高知大学の石塚英男博士, 吉倉紳一 教授には御荷鉾帯の生成等について御教示いただいた。 粘土鉱物の分析には高知大学の東正治教授, 中川晶二博 士に御教示いただいた。さらに群馬大学の佐藤満雄教授, 農林水産省国際農林水産業研究センター八田珠郎博士, 岩手大学大河原正文先生, 前科学技術庁防災科学研究所 田中耕平室長諸氏に種々の御教示をいただいたここに 感謝の意を表します。 


\section{参考文献}

1 ) Takeda, K.: Geological and Petrological Studies of the Mikabu Greensones in Eastern Shikoku, Southwest Japan. Journal of Science of the Hiroshima University Series C, Vol. 8, No.3, September, PP220-280, 1984.

2 ）鹿園直建：地球システムの化学, 東京大学出版会, PP164, PP 204, 1997.

3 ）大貫仁・吉田武義・花松俊一：みかぶ緑色岩帯の岩石化学, 地球, Vol. 10, No. 6, PP398-401, 1988.

4) Hashimoto, M.: Reactions producing actinolite in basic metamorphic rocks, Lithos, 5 , PP19-31, 1972.

5 ）須鉿和已他：日本の地質 8 「四国地方」, 共立出版侏, PP50 $-63,1991$.

6 ）小澤大成：みかぶ帯の特徎と火成年代, 総合研究 (A), 付加 带形成に打ける緑色岩の意義, 研究報告, No1, PP101107, 1996.

7 ）寺戸恒夫：四国島内における大規模崩壊地形の位置づけと課 題, 地すべり学会関西支部, PP32-44, 1995.

8 ）鈴木克士：地質学から見た御荷錵地すべりの特性，地すべり 学会関西支部, PP17-31, 1983.

9 ）木村敏雄：地質構造の科学, 朝倉書店, PP128 , 1984.

10）森清寿朗：徳島県剣山地方みかぶ緑色岩類の岩石学的研究, 地質学雑誌, 第85巻第 6 号, P299-306, 1979.

11）周藤賢治・牛来正夫：地殼・マントル構成物質，共立出版(侏， PP36, 1977.

12) Stephen, I. - MacEwan, D. M. C.: Clay Miner. Bull., 1, PP
$157,1951$.

13) Stefano, C. et al : Weathering of Chlorite to a Low-Charge Expandable Mineral in a Spodosol on Apennine Mountains, ITALY, Clays and Clay Minerals, Vol. 45, No. 1, PP28-41, 1997.

14）一國雅巳：風化過程における元素の移動度, 粘土科学 32 巻 1 号PP6, 1992.

15）地学団体研究会：新版地学事典, 平凡社, PP1403, 1996.

16）都城秋穂：変成岩と変成带, (侏岩波書店, PP256, 1967.

17）都城秋穂：変成作用, (侏)岩波書店, PP27, 1994.

18）加藤芳明：地形と土壤, 東海大学出版会, PP80-81, 1980.

19）八木則男 - 矢田部龍一 - 松村真一郎 - 田中博文 - 真嶋钽之 · 向谷光彦：地すべり粘性土のクリープ特性, 土木学会四国支 部, PP278, 1996.

20）守随治雄：地すべり粘土中の混合層鉱物，土と基礎，Vol. 33, No. 4, PP95-96, 1985.

21）千木良雅弘：風化と崩壊, 近未来社, PP129, 1995.

22）佐藤修：地すべり地における地下水水質調查法，地すべり, Vol. 21, No $1 \sim 3,1993$.

23）夕部雅丈・佐藤修：緑色岩の風化と地すべり粘土，地盤工学 会四国支部, PP $1-4,1996$.

24） G. V. ブォイトケブィッチ・V. V. ザクルートキン・岸本文男 訳：地球化学原論, 現代工学社, PP $368,1983$.

25）松井義人 - 坂野昇平 : 岩石・鈗物の地球化学, 侏岩波書店, PP38-39, 1994

（原稿受理日 平成11年12月20日） 
すべり面三次元構造と地すべり地塊運動特性

「地すべり」Vol. 37, No. 3 (通巻143号) pp. 32 41，2000年（平成12年）12月

佐々木一郎, 新谷 融

本研究は，斜面変動の一つである地すべりのうち，地塊型平面地すべりに形態分類された形態 I， II ， III 取り上げ，一つの近似平面地すべり面上の比較的単純な地質構成体からなる典型的地塊型地すべり災害地の調 査結果をもとに, すべり面構造・運動様式・変動地形の関係を考察し, 地すべり地塊運動をすべり面構造によ る運動学的考察とその模型実験とによってこれらの関係を検証し，モデル化したものである。本モデルは，地 すべり対策を地すべりの運動実態に適応するための，地すべり地塊三次元運動機構解明の基礎を提供するもの と考える。

\section{四国中央部御荷鉾帯の緑色岩の風化と地すべり(1)}

「地すべり」Vol. 37, No. 3 (通巻143号) pp. 32 41，2000年（平成12年）12月

夕部雅丈, 岡村 眞, 矢田部龍一, 八木則男, 横田公忠, 佐藤 修

四国中央部の高知県に分布する御荷鉡緑色岩類帯では, 片状の緑色岩帯で地すべりが多発している。そこで 片状の緑色岩の風化と地すべりの関係について水質分析, 蛍光X線分析, X線回折分析により, 調査した結果, 片状の緑色岩は主としてアクチノライトとクロライトで構成されており，風化はアクチノライトのCaとアク チノライトとクロライトの $\mathrm{Mg}$ が溶脱し, 風化帯内の浅いすべりの場合には, 主としてクロライトの $\mathrm{Mg}$ 溶 脱によってスメクタイトが生成し，すべり面粘土となって地すべりが滑動していることがわかった。

\section{四国の地すべりの一般的特性}

「地すべり」Vol. 37, No. 3 (通巻143号) pp. 50 56, 2000年（平成12年）12月

矢田部龍一, 横田公忠, 石井朋紀, 夕部雅丈

四国の地すべりの一般的特性を第三紀層地すべりのそれと比較しながら検討した。そして，四国の地すべり の勾配の方が $10^{\circ}$ 程急であること, すべり面深度と地すべりの長さの比が大きいこと, 地下水位が比較的深い こと, せん断強度に影響する鉱物としてはクロライトやマイカが支配的であること, 残留状態でのせん断抵抗 角が若干大きいことなどが分かった。

\section{排水ボーリングの削孔事例からみた地質状況と削孔精度に関する考察}

「地すべり」Vol. 37, No. 3 (通巻143号) pp. 57 62, 2000年（平成12年）12月

藤原聖一, 高橋英一, 斉藤 蒙

地すべり対策工事の一つである排水ボーリング工は, 地形条件, 流末施設, 用地の制約などの理由により排 出目標位置が制限されるため, 高い削孔精度が要求される。

我社で過去 3 年間に施工した排水ボーリング工の事例を解析した結果, 排水ボーリング工の削孔精度は, 削 孔長と地質状況に深く関連し, たとえば, 土質区分上で岩塊・玉石混じり土を削孔対象とした場合は, $60 \mathrm{~m}$ 程 度以内が限界であると考えられる。 